was honorary secretary of the Chemical Society for nine years and afterwards vice-president, and he was elected to the Royal Society in 1931. In 1938 he presided over Section B of the British Association. He also did important work as a secretary of the Academic Assistance Council. His successor at Guy's Hospital, Prof. G. A. D. Haslewood, is to be professor of chemistry and biochemistry and will be assisted by a reader in physical and inorganic chemistry.

Leather Industries at Leeds:

Prof. D. McCandlish

Prof. Doygufolochandish, who is retiring from the chair of 3 er industries in the University of Leeds, ws the Department under the lace PM. H. R. Procter. After the award of his M.Sc. de Hee hecame chief chemist in the well-known upper-leather tannery of A. F. Gallun and Sons in Milwaukee, U.S.A. Returning to Great Britain in 1919, he was appointed to the chair at Leeds. Prof. McCandlish's researches have ranged widely within the field of leather technology, on ehrome tanning, measurement of $p \mathrm{H}$ value, the atmospheric deterioration of leather, the molecular structure of collagen in relation to the vegetable-tanning process, and various aspects of the analysis of tannins and leather; he edited the handbook on quantitative tannin analysis for the British Section of the International Society of Leather Trades' Chemists. During the Second World War he was active in overcoming shortages of essential materials. Prof. McCandlish has been president of the International Society of Leather Trades' Chemists, and was its treasurer for about twenty-seven years, up to its dissolution in 1947. $\mathrm{He}$ was president during 1926-27 of the British Section (now the Society of Leather Trades' Chemists), and his counsel, always available, has been a great stabilizing influence in the Society. He has been a co-opted member of council of the British Leather Manufacturers' Research Association since its inception in 1920, and chairman of the advisory committee on leather subjects of the City and Guilds of London Institute for more than twenty years. He has also played his part in the social and civic life of Leeds.

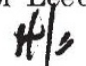
McCandlish in the chat of leather industries in the University of Lo graduated at Leeds with firstclass honour 100 th chemistry and the chemistry of leather if nulfacture. He was then appointed research as 1 nt to the late Prof. H. R. Procter, and later bejole assistant lecturer and demonstrator. After service with the King's Own Yorkshire Light Infantry during the First World War, he returned to the University and has been lecturer and senior lecturer under Prof. McCandlish since 1919. Mr. Atkin's research work has covered a wide field, and includes studies on hide proteins, vegetable tannins, the chemistry of chromium compounds, and the deterioration and preservation of vegetable-tanned leathers. In conjunction with the late F.C. Thompson, he re-wrote Procter's "Leather Chemists' Pocket Book", which is recognized as the standard text-book on analysis of materials used in the leather industry. $\mathrm{He}$ was a member of a small committee which edited the "Official Methods of Analysis" of the International Society of Leather Trades' Chemists, and has served that Society in many capacities. He was president during 1938-39 and continued as acting-president during the War years. For many years he was honorary editor of the Society's Journal.

\section{British Academy}

At the annual meeting of the British Academy, the following wepo elected officers: President, Sir $\mathrm{H}$. Idris Bell i Secretary, Dr. R. E. Mortimer Wheeler; Treasurey, Sir Frederic Kenyon; New Members of Councix, Sir Alfred Clapham, Prof. H. A. R. Gibb, Dr. WW. W. Greg, Sir David Ross, Sir Percy Winfield and Prof. C. H. Dodd. Lord Russell was elected an honorary fellow, and Prof. C. W. Blegen, professor of classical archæology in the University of Cincinnati, Prof. W. B. Dinsmoor, professor of archæology in Columbia University, New York, and M. Georges Lefebvre, of the Sorbonne, have been elected corresponding members. The following have been elected fellows: Prof. A. J. Arberry, Sir T. Adams's professor of Arabic, University of Cambridge; Dr. R. W. Chapman, formerly secretary to the Delegates of the Oxford University Press ; Sir Kenneth Clark, Slade professor of fine art, University of Oxford; Prof. D. C. Douglas, professor of history, University of Bristol; Prof. R. W. Firth, professor of anthropology, University of London; the Rev. W. F. Howard, principal of Handsworth College, Birmingham, and lecturer in Hellenistic Greek in the University of Birmingham; Prof. J. E. Neale, Astor professor of English history, University of London; Mr. R. C. F. O. Pfeiffer, lecturer in classical scholarship, University of Oxford; and Mr. A. E. Popham, keeper, Department of Prints and Drawings, British Museum.

\section{Medal of the Society of Chemical Industry: Dr. Foster D. Snell}

ON July 13/during the annual general meeting of the Society of Chemical Industry, held in Whitworth Hall, University of Manchester, the president, Sir David Rivett, presented the Medal of the Society to Dy. Foster D. Snell. Dr. Snell is a consulting chemist and chemical engineer in New York and is an active member of the American Section of the Society of Chemical Industry, of which he was chairman during 1942-44. The Medal is awarded not more than once every two years for conspicuous services to applied chemistry by research, discovery, invention or improvement, or to the Society in furtherance of its objects, and it is not necessarily restricted to a member.

\section{Technical Education in Britain}

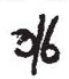

IN presenting the Edgucation Estimates for 1949-50 in the House 19 Cofimons on July 5, the Minister of Educatign, Tomlinson, referred to the imperative necgosifor foffing the schools and colleges adequately in moers and in quality, and said that the number of Graduate teachers in schools is steadily increasing. While there are difficulties with teachers of science, the position is being closely watched and it is too early to say that the teaching of science in the schools of Britain is in jeopardy through a lack of good graduate recruits to the teaching profession. Of all further education, Mr. Tomlinson said he believes that technical education is to-day the most important; in 1948 the Ministry approved final plans for projects for technical education to cost nearly $£ 2$ million, and preliminary plans for another $£ 3.5$ million. He said he is going ahead with the 
establishment of national colleges of technology wherever industry is prepared to co-operate, and five are already open. A further one at Bradford for wool has been approved in principle, as well as two others. Other problems in the higher technological field are being considered by the National Advisory Council on Education in Industry and Commerce in congultation with the University Grants Committee. 8y:

\section{University Entrance Awards and Scholarships}

Wiтн regard to university awards and scholarships, Mr. Tomling ponounced that he proposes to carry out the recifmendations made by the working party on th 4 ject in Chapter 4 of its report. These re or henlations, which are to be put into effect fo thwith, include revision of the income scale for parental contributions on more adequate and up-todate lines, the assessment of grants and contributions on the basis of a full year, and larger children's and education allowances. There is also to be an increase by one hundred this year in the number of State scholarships. The vice-chancellors of universities and the local education authorities are already in consultation about a procedure for local awards under which full weight will be given to the recommendations of universities on the merits of students. $\mathrm{He}$ hoped in the future to tidy up the grants to intending teachers; but this must be done by stages. Before long he hoped to abolish the system of four-year grants based on an undertaking by the individual teacher. Mr. Tomlinson did not think that there is any evidence that the standard of students leaving the schools has declined.

The Minister has thus accepted substantially the recommendations made earlier in a report "Entrance to the Universities" prepared by the Education Advisory Committee of the Workers' Educational Association and adopted by the annual conference in October 1948. A "Comment" on the working party's proposals now appended to this report expresses the view that, if fully implemented, the working party's report should provide the best means of discovering the real scale of the demand for university places and how far the supply is adequate. It should pave and not block the way for the inquiry into a long. term policy with regard to the universities which was urged in the report from the Workers' Educational Association's committee and endorsed by the conference. These questions, it was urged, should be investigated by a committee consisting of representatives of the universities, the Ministry of Education, the Treasury, teachers, industry and men and women representatives of other aspects of our national life. Besides the number of university places to be provided and the question of the selection of university students, the function of the university in the national life of Britain, the length of the university course, the proportion of general and special education in a first degree, the recruitment and training of university teachers, adult students at universities and the interchange of students with the Dominions and overseas generally were $r$ pommended for investigation.

\section{Electrik Power Engineering in Germany during the War}

B.I.O.S. Oyprall Report No. 11 ("Electric Power Engineering Gefefmany during the Period 1939194.." P. 56. London: H.M. Stationery Office. 1s. If f f views developments in electrical power practice trder five headings: turbines, generators and motors; switchgear, transformers and other equipment for the transmission system; power cables ; mercury-arc rectifiers ; batteries and battery traction. Each section of this publication, which, in fact, epitomizes a group of individual summary reports, presents a picture of the position in that field in Germany at the end of the War, makes some assessment of the most significant developments and contrasts the German position with that existing in Great Britain. This last-mentioned feature adds greatly to the value of the document. The report concludes with an extensive list of references to other detailed reports and to original German documents, and is not only an informative record but also constitutes a valuable critical comparison of British and German development. It merits the attention of all concerned with either the manufacturing or the supply side of the electrical industry.

\section{Astronomy Gallery at the Science Museum, Kensington}

THE Astroxomy Gallery at the Science Museum, South Kensington, London, S.W.7, is now fully open to the public after having been closed since the outbreak of the War. Among the many exhibits once again on view are historic telescopes, models of the solar system including an orrery made for George III, sundials, sextants and several historic globes. An exhibit now shown for the first time is one presented by H.M. The King - a globe upon which is engraved a representation of the visible surface of the moon. Constructed by John Russell, R.A., in 1797, the globe is known as a selenographia, and it is supported in a complicated mounting upon which the motions of the moon can be demonstrated. In the course of a month the moon, as seen from the earth, appears to oscillate slightly, and a small part of the surface, first on one edge and then on the other, is exposed. The result is that 59 per cent of the surface can be observed; but the other 41 per cent has never been seen. The mechanical mounting of the selenographia enables these oscillations, or 'librations', of the moon to be demonstrated in detail.

\section{Training for Management}

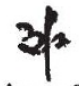

AN interesting attempt to provide training for management or spudents who have had little or no industrial exp. Hence has recently been announced by the Ifeich College of Technology and Commerce. Whe fourse has been arranged to combine courses of sthely with the acquiring of practical experience. All students have to be nominated by a firm or organisation with whom they are working, and are required to attend at the School of Commerce for three separate months of residence spread over a total period of thirteen months. During the remaining ten months a course of directed reading is prescribed, suitable study notes being provided by the College; each student is required to attend the College for tutorial sessions on two occasions during each reading period. The course itself will cover the Common Intermediate Examination in Management and will allow the student to sit for the National Diploma in Management after a further two years of part-time study.

\section{Experimental Cel/ Research}

A NEW journal entitled Experimental Cell Research is being jssued under the auspices of the International Society for Cell Biology. It will publish papers dealing with experimental analysis of the 